\title{
The effect of tyrosine kinase inhibitors, tyrphostins: AG1024 and SU1498, on autocrine growth of prostate cancer cells (DU145)
}

\author{
Joanna Kisielewska, Janusz Ligęza, Andrzej Klein \\ Department of General Biochemistry, Faculty of Biochemistry, Biophysics and Biotechnology, Jagiellon- \\ ian University, Cracow, Poland.
}

\begin{abstract}
It is well established that autocrine growth of human prostate cancer cell line DU145 is dependent on TGF (EGF)/EGFR loop. However, the participation of several other growth factors in proliferation of DU145 cells has been also proposed. We employed two selective tyrosine kinase inhibitors (tyrphostins): AG1024 (an IGFIR inhibitor) and SU1498 (a VEGFR2 inhibitor) for growth regulation of DU145 cells, cultured in chemically defined DMEM/F12 medium. Both the tested compounds inhibited autocrine growth of DU145 cells at similar concentration values (IC50 $\approx 2.5 \mu \mathrm{M})$. The tyrphostins arrested cell growth of DU145 in G1 phase, similarly as inhibitors of EGFR. However, in contrast to selective inhibitors of EGFR, neither AG1024, nor SU1498 (at concentration $\leq 10 \mu \mathrm{M}$ ) decreased the viability of the investigated cells. These results strongly suggest that autocrine growth of DU145 cells is stimulated by, at least, three autocrine loops: $\mathrm{TGF} \alpha(\mathrm{EGF}) / \mathrm{EGFR}$, IGFII/IGFIr and VEGF/VEGFR2(VEGFR1). These data support the hypothesis of multi-loops growth regulation of metastatic prostate cancer cell lines.
\end{abstract}

Key words: Tyrphostins - DU145 cells - Autocrine growth regulation

\section{Introduction}

The development of the normal prostate is regulated by stromal-epithelial interactions via endocrine and paracrine factors (mainly androgens, growth factors and cytokines) $[1,2]$. Prostate cancer cells shifts from an androgen-dependent to an androgen-independent state with a concomitant switch from endocrine/ paracrine to autocrine growth regulation [3]. An important early event in the development of the neoplastic phenotype is the induction of genes involved in autocrine growth, such as growth factors and its receptors $[4,5]$. Therefore, an analysis of deregulation of the functional relationship between autocrine growth factors and their receptors is essential in determining the pathogenesis and growth regulation of prostate cancer. This is emphasized by current evidence obtained from clinical specimens and in vitro experiments. Various

Correspondence: A. Klein, Dept. of General Biochemistry, Faculty of Biochemistry, Biophysics and Biotechnology,

Jagiellonian University, 30-387 Cracow, Gronostajowa 7, Poland; e-mail: andrzej.klein@uj.edu.pl autocrine loops (EGF/EGFRs, NGF/NGFR, VEGF/VEGFRs, IGFs/IGFRs and FGFs/FGFRs) have been postulated as regulators of prostate cancer cells growth [6-11], however, only the first proposition is well documented. An increased production of transforming growth factor $\alpha$ (TGF $\alpha$ ) was found in several prostate cancer cell lines, including DU145, and the addition of anti-EGFR to DU145 cell culture inhibits cell proliferation $[12,13]$. Moreover, the use of synthetic inhibitors of EGFR tyrosine kinase inhibited proliferation of androgen-dependent and androgenindependent prostate cell lines [14-16]. An increased level of insulin-like growth factors (IGFs) and vascular endothelial growth factor (VEGF) was observed in patients with prostate cancer $[8,17,18]$. It was proposed that IGFs affect the growth of prostate cells by activation of EGFR [19] and that VEGF may be an

Abbreviations: PDGF - platelet-derived growth factor; EGF - epidermal growth factor; FGF - fibroblast growth factor; IGF insulin-like growth factor; NGF - nerve growth factor; R - receptor; TGF - transforming growth factor VEGF - vascular endothelial growth factor. 
autocrine mediator of prostate cell motility and a paracrine angiogenic factor rather than an autocrine growth factor [20].

Despite many experiments published today, only a few of them are associated with autocrine regulation of prostate cancer cells, and the mechanism(s) of autocrine growth of these cells is far from explanation. We do not know whether the same cancer cell may be regulated by one or by several autocrine loops. Determination of the interaction between many autocrine loops of neoplastic cells may explain the mechanism of neoplastic growth and resistance of cancer cells to single tyrosine kinase inhibitors, observed in anticancer therapy.

A useful tool in the investigations of autocrine growth regulation of cancer cells is found in inhibitors of tyrosine kinases [21-23]. A series of small-molecular compounds known as tyrphostins were recently developed as tyrosine kinase inhibitors by Levitzki and Gazit [24]. In the present work, we tested two tyrphostins: AG1024 (a selective inhibitor of IGFIR) [25] and tyrphostin SU1498 (a specific inhibitor of VEGFR2) [26,27] in the growth regulation of DU145 human prostate cancer cells.

\section{Materials and methods}

Chemicals and reagents. Dulbecco's modified minimal essential medium (DMEM), Minimal Essential Medium (MEM), Hoechst No 33258, propidium iodide and tyrosine kinase inhibitors: AG1024 $\left(\mathrm{IC}_{50}=0.4 \mu \mathrm{M}\right)$ and SU1498 $\left(\mathrm{IC}_{50}=0.7 \mu \mathrm{M}\right)$ were purchased from Sigma (St. Louis, Mo., USA). Fetal bovine serum (FBS) was obtained from Biowest, South American Origin. Other reagents were provided by POCh (Gliwice, Poland).

Stock solutions of the tyrphostins were prepared by dissolving the compounds in dimethylsulfoxide (DMSO) to final concentration $50 \mathrm{mM}$ and storing the resultant solutions at $-20^{\circ} \mathrm{C}$. DMEM/F12 (1:1) medium was used do dilute stock solutions to working concentrations $(0.1-10 \mu \mathrm{M})$.

Cell culture. DU145 (HTB-81) cells were obtained from the American Type Culture Collection (ATCC) and cultured in MEM, supplemented with $100 \mathrm{IU} / \mathrm{ml}$ penicillin and $100 \mathrm{mg} / \mathrm{ml}$ streptomycin in the presence of $10 \%$ fetal bovine serum (FBS). The cells were passaged two times per week.

Cell proliferation assay. Target cells were seeded on 96-well plates at concentrations of $5 \times 10^{3}$ cells/well in (MEM), supplemented with 100 I.U./ml penicillin and $100 \mathrm{mg} / \mathrm{ml}$ streptomycin in the presence of $10 \%$ FBS. Following $24 \mathrm{~h}$ of incubation, the culture medium was replaced with serum-free DMEM/F12 (1:1) supplemented with transferrin $(5 \mathrm{mg} / \mathrm{ml})$, sodium selenite $(2 \mathrm{ng} / \mathrm{ml})$ and albumin $(0.5 \mathrm{mg} / \mathrm{ml})$ [DMEM/F12+]. After additional $24 \mathrm{~h}$ of incubation (Day 0), the medium was replaced with serum-free DMEM/F12+ medium containing tyrosine kinase inhibitors: AG1024, SU1498 (0.1-10 $\mu \mathrm{M})$. The incubation was continued for the next $48 \mathrm{~h}$ at $37^{\circ} \mathrm{C}$ in humidified atmosphere. The modified crystal violet staining method (CV) [28] was used to determine the influence of the tyrphostins on proliferation of target cells. The absorbance was measured using a Tecan (Spectra Fluor Plus) multiscan plate recorder. Ten replicate wells were used for each experiment.
The influence of tyrosine kinase inhibitors was expressed as a relative (to the controls) decrease in cell growth determined after $48 \mathrm{~h}$ of incubation with the investigated compounds. The calculated parameter was:

$$
G_{i}=\frac{\bar{A} i-\bar{A}_{0}}{\bar{A}_{C}-\bar{A}_{0}} \cdot 100 \%
$$

where: Ao, Ac, Ai - average values of absorbance at $540 \mathrm{~nm}(\mathrm{CV})$ or $570 \mathrm{~nm}$ (MTT) of the control sample at the start of experiment (Ao), control sample after $48 \mathrm{~h}$ of incubation (Ac) and after $48 \mathrm{~h}$ of incubation with the investigated inhibitors (Ai).

Assessment of cell viability. Differential staining method (Hoechst 33258/PI) was used in the investigation of the effect of tyrphostins AG1024 and SU1498 on the viability of DU145 cells [29]. The cells were seeded on $24-w e l l$ plates at a density $2 \times 10^{4}$ per well in $0.8 \mathrm{ml}$ MEM with $5 \%$ FBS. Following $24 \mathrm{~h}$ of incubation, the culture medium was replaced with serum-free DMEM/F12+ medium. After additional $24 \mathrm{~h}$ of incubation, the cells were exposed to $10 \mu \mathrm{M}$ concentrations of the investigated tyrphostins and $50 \mathrm{nM}$ of taxol. The experiment was carried out for $48 \mathrm{~h}$ and then Hoechst No 33258 and propidium iodide were added to the final concentration of $5 \mu \mathrm{g} / \mathrm{ml}$ and $1 \mu \mathrm{g} / \mathrm{ml}$, respectively. After $15 \mathrm{~min}$, the cells were directly examined on plates with a fluorescent Olympus IMT 2 microscope. Two excitation filters were used: one allowing for excitation of both dyes, the other - only PI. The Image $J$ software was used for image processing (emerging RGB channels, enhancing contrast and sharpening) and the quantitative analysis of the processed pictures (cell counting). It allowed for estimating the fraction of dead cells (PI/DNA signal), viable cells (Hoechst 33258/DNA signal), and apoptotic cells (Hoechst 33258/DNA signal with morphological changes characteristic of last-phase apoptosis). Each experiment was repeated at least six times. Images with the number of cells exceeding approximately 100 were selected for the analysis.

Cell cycle analysis. To estimate the proportion of cells in various phases of cell cycle, cellular DNA contents were measured by flow cytometry (FACS). Cells $\left(8 \times 10^{3} /\right.$ well) were plated on 6 -well plates, in MEM supplemented with $10 \%$ FBS and sodium pyruvate (MEM-NEAA), and allowed to attach overnight. Subsequently, the cells were placed in DMEM/F12+ and incubated for another $24 \mathrm{~h}$. After this time, $10 \mu \mathrm{M}$ AG1024 or SU1498 were added to the investigated cells. Forty-eight $h$ after tyrphostins addition, the cells were harvested by trypsinization and centrifuged. The pellets were suspended in $0.5 \mathrm{ml}$ of cold PBS and washed twice. The centrifuged pellets were suspended in $70 \%$ ethanol, fixed at $4^{\circ} \mathrm{C}$ for $2 \mathrm{~h}$ and centrifuged $(7 \mathrm{~min}$ at $280 \times \mathrm{g}$ ). The pellets were then re-suspended in $5 \mathrm{ml}$ of PBS and centrifuged again. The cells were stained with $1 \mathrm{ml}$ of propidium iodide (PI) solution $(0.2 \mathrm{mg}$ of RNAse A, $0.02 \mathrm{mg}$ PI, $1 \mathrm{ml}$ Triton $\mathrm{X}-100)$. Each sample was incubated at $37^{\circ} \mathrm{C}$ for $30 \mathrm{~min}$. DNA content was determined by the use of a FACScan Beckton-Dickinson flow cytometer.

Statistical analysis. The statistical analysis was performed with the use of the Statistica 6 program. The effects of different tyrphostins concentrations on DU145 cells proliferation were analyzed using one way ANOVA, followed by the Dunnett's test. The Mann Whitney U test was used to determine differences in the percentage of alive, apoptotic and necrotic cells in the control sample versus tyrphostins or taxol (paclitaxel) treated samples. Differences were considered significant at $p<0.05$. The mean \pm SEM of at least ten replicates $(\mathrm{CV})$ or four replicates (differential staining method) were used for statistical comparison. 

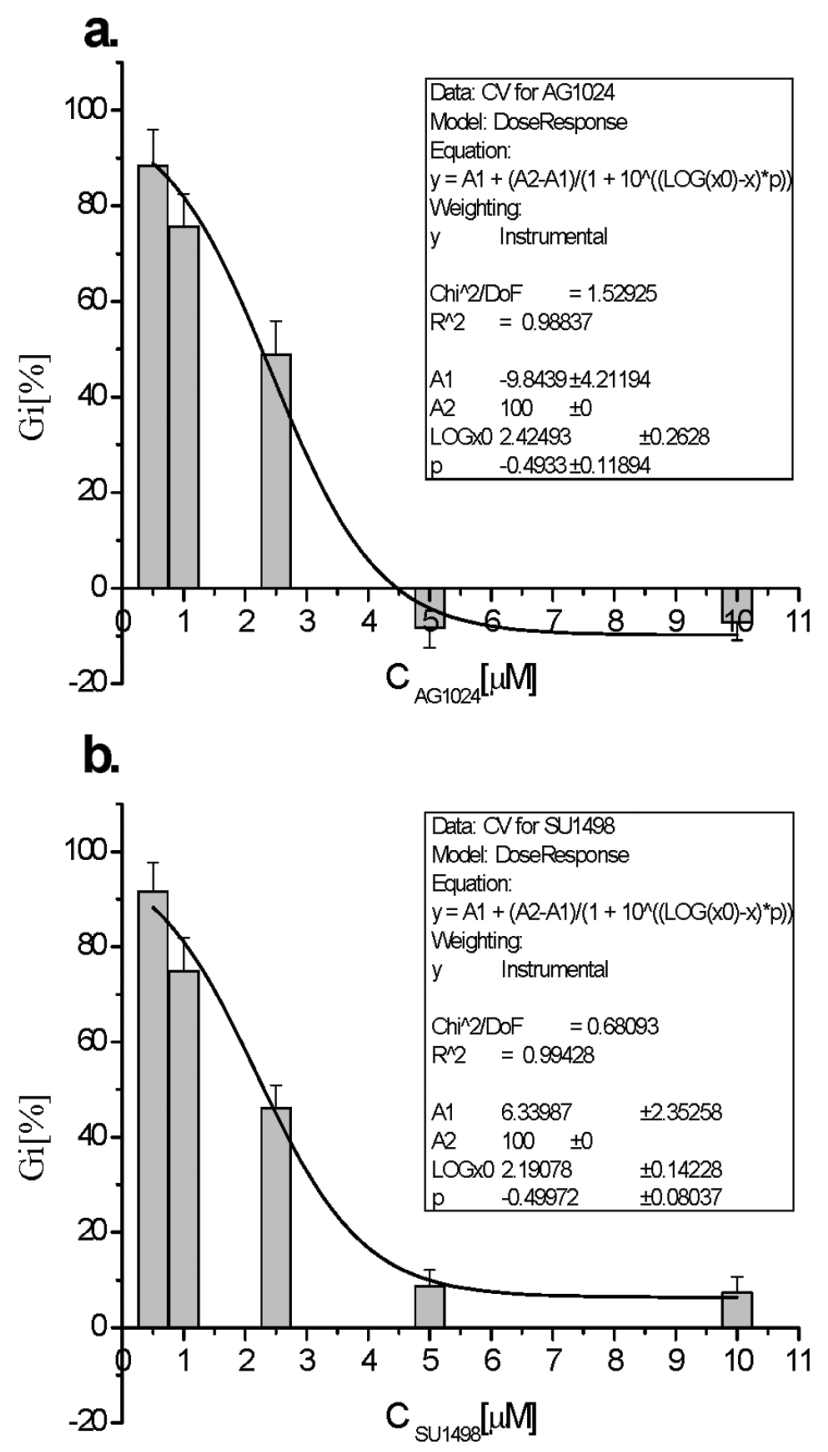

Fig. 1. The dose-dependent effect of tyrphostins: AG1024 (a) and SU1498 (b) on the growth of DU145 cells after $48 \mathrm{~h}$ of incubation in serum-free DMEM/F12+ medium.

\section{Results}

\section{Effect of tyrphostins AG1024 and SU1498 on DU145 cell proliferation}

Human prostate DU145 cells were exposed for $48 \mathrm{~h}$ to tyrosine kinase inhibitors, AG1024 and SU1498, added at the concentration range of $0.5-10 \mu \mathrm{M}$. The effect of the investigated tyrphostins determined by the CV method is shown in Table 1. The exposure of prostate cells to tyrphostins AG1024 and SU1498 at concentration $\geq 1 \mu \mathrm{M}$ resulted in a dose-dependent suppression of proliferation compared to the controls. Both tyrphostins caused a similar effect on growth inhibition (Gi) of DU145 cells. The growth of the investigated cells, determined by the CV method, was practically completely inhibited at concentration $10 \mu \mathrm{M}$, Gi was $107.2 \pm 3.75$ and $92.7 \pm 3.36$ for AG1024 and SU1498, respectively.
Table 1. The influence of AG1024 (a) and SU1498 (b) on the autocrine growth of DU145 cells, determined by crystal violet (CV) method.

\begin{tabular}{|c|c|c|c|c|}
\hline & $\mathrm{A}_{540} \mathrm{~nm}$ & SEM & \multicolumn{2}{|c|}{ Dunnett } \\
\hline \multicolumn{5}{|c|}{ (a) } \\
\hline Control & 0.6785 & 0.01824 & $\downarrow$ & $* *$ \\
\hline $0,5[\mu \mathrm{M}]$ & 0.6395 & 0.01931 & ns & ** \\
\hline $1[\mu \mathrm{M}]$ & 0.5971 & 0.01823 & $* *$ & $* *$ \\
\hline $2,5[\mu \mathrm{M}]$ & 0.5074 & 0.02165 & $* *$ & $* *$ \\
\hline $5[\mu \mathrm{M}]$ & 0.3160 & 0.01248 & $* *$ & ns \\
\hline $10[\mu \mathrm{M}]$ & 0.3201 & 0.01107 & $* *$ & ns \\
\hline Ao & 0.3441 & 0.00536 & $* *$ & $\uparrow$ \\
\hline \multicolumn{5}{|c|}{ (b) } \\
\hline Control & 0.6507 & 0.01532 & $\downarrow$ & $* *$ \\
\hline $0,5[\mu \mathrm{M}]$ & 0.6253 & 0.01215 & ns & $* *$ \\
\hline $1[\mu \mathrm{M}]$ & 0.5737 & 0.01831 & $* *$ & $* *$ \\
\hline $2,5[\mu \mathrm{M}]$ & 0.4857 & 0.01223 & $* *$ & $* *$ \\
\hline $5[\mu \mathrm{M}]$ & 0.3704 & 0.00948 & $* *$ & ns \\
\hline $10[\mu \mathrm{M}]$ & 0.3664 & 0.00896 & $* *$ & ns \\
\hline Ao & 0.3441 & 0.00536 & $* *$ & $\uparrow$ \\
\hline
\end{tabular}

$\uparrow$ - statistical significance (compared to control); $\uparrow$ - statistical significance (compared to day "0" [A0]); *** - p $<0.001, * *-0.01<\mathrm{p}<0.001, *-0.05$ $<\mathrm{p}<0.01, \mathrm{~ns}-$ not significant

A 50\% inhibition of the growth of DU145 cells was determined by fitting a sigmoidal-model of the dosedependent effect of the investigated tyrphostin (Fig. 2), calculated from the equation:

$$
H[\% K]=\frac{100}{1+10^{\log \left(I C_{50}-C_{\text {thh }}\right) \cdot p}}
$$

$\mathrm{IC}_{50}$ coefficients calculated from the growth inhibition curves were $2.19 \pm 0.14 \mu \mathrm{M}$ and $2.42 \pm 0.26 \mu \mathrm{M}$ for SU1498 and AG1024, respectively. The results showed a similar cytostatic activity against DU145 cells of both the investigated tyrosine kinase inhibitors. The anti-proliferative activity was about 6 times lower for AG1024 (IC50 $=0.4 \mu \mathrm{M})$ and 3 times lower for $\mathrm{SU} 1498\left(\mathrm{IC}_{50}=0.7 \mu \mathrm{M}\right)$ than the enzyme inhibitory activity of the investigated tyrphostins.

\section{Effect of CM on target cell viability}

The investigated tyrosine kinase inhibitors were also examined for their cytotoxic potential and the ability to induce tumor cell apoptosis or necrosis. The influence of tyrphostins AG1024 and SU1498 on target cell viability was assessed after double-staining with Hoechst 

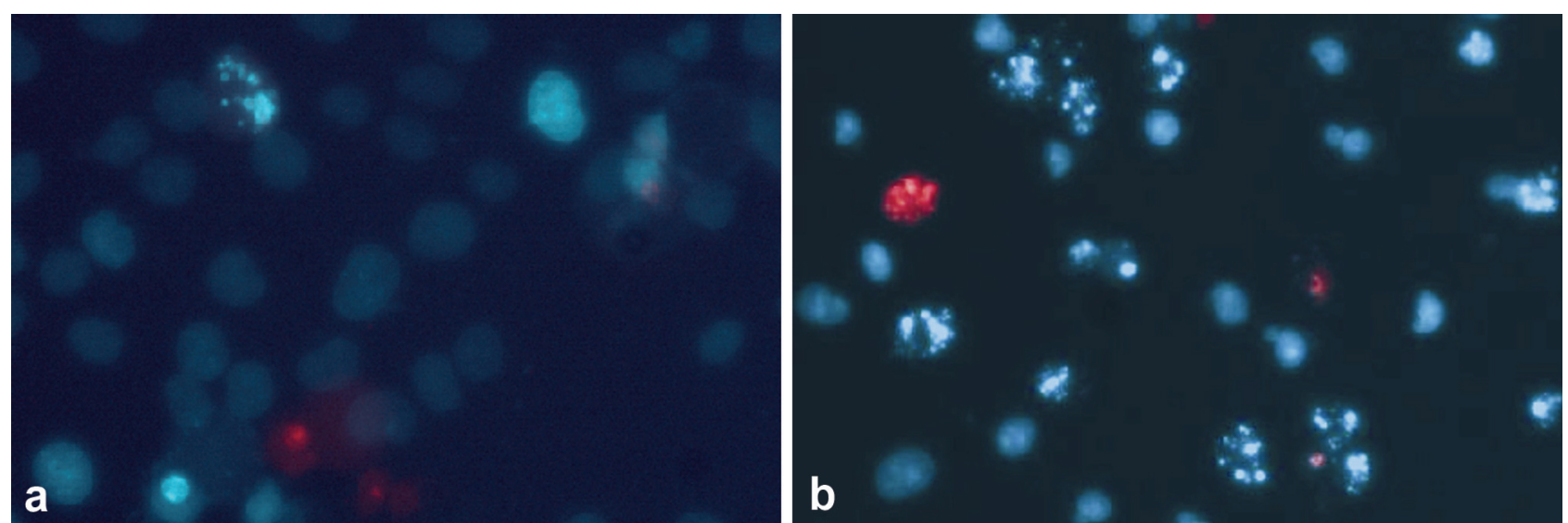

Fig. 2. A typical picture of the cultures of DU145 cells after $48 \mathrm{~h}$ of incubation with $10 \mu \mathrm{M}$ AG1024 (a) and $50 \mathrm{nM}$ of taxol (b). Dark blue - viable cells, blue (with nuclear fragmentation) - apoptotic cells, red - necrotic cells

33258 and propidium iodide. Viable cells were dyed on blue, apoptotic on light-blue and necrotic cells on red. Apoptotic cells were clearly distinguishable by their characteristic morphology (cytoplasmic blebbing, cell shrinkage, nuclear condensation and fragmentation) (Fig. 2). The results of quantitative determination of the number of viable, apoptotic and necrotic cells are presented in Figure 3. The investigated receptor kinase inhibitors influenced the viability of DU145 cells in a similar manner after $48 \mathrm{~h}$ of incubation in the serum-free medium. In the case of the control culture, the amount of apoptotic and necrotic cells did not exceed $1.89 \pm 0.25 \%$ and $0.2 \pm$ $0.1 \%$ of the entire cell population. The viability of DU145 cells cultured with AG1024 and SU1498 was in the range $91.2-91.7 \%$ of the entire cell population, regardless of the kind tyrphostin used. The percentages of apoptotic cells after incubation with AG1024 and SU1498 were $7.75 \pm 0.73$ and $5.81 \pm 0.93$, respectively. The number of necrotic cells differed from $1.09 \pm$ $0.22 \%$ in the case of AG1024 to $2.48 \pm 1.05 \%$ in the case of SU1498. The comparison of these results with the effect of $50 \mathrm{nM}$ taxol $(79.55 \pm 4.07 \%$ of apoptotic and $14.00 \pm 2.99 \%$ of necrotic cells) indicates that both investigated tyrphostins, used in the concentration $\leq 10$ $\mu \mathrm{M}$ are weakly cytotoxic for DU145 cells. These results were confirmed by the flow cytometry method. The number of apoptotic and necrotic cells after DU145 incubation with AG1024 and SU1498 was similar.

\section{Influence of AG1024 and SU1498 on cell cycle of DU145 cells.}

DNA content of DU145 cells was determined by the use of a flow cytometer FACScan Beckton-Dickinson after $48 \mathrm{~h}$ of incubation with the investigated compounds. The results are summarized in Table 2. Similar differences as compared with the control cell cul- ture were observed after DU145 treatment with both investigated tyrphostins. An increase in the number of cells was about $15 \%$, while the fraction of cells synthesizing DNA decreased by about $50 \%$. The proportion of cells in faze G1 to G2 changed from 2.78 (control) to 4.61 in the case of AG1024 and 4.43 in the case of SU1498 (Table 2).

\section{Discussion}

Understanding the molecular mechanisms that regulate prostate cancer growth may help in developing clinical strategies for the treatment of the disease. Several peptide growth factors, including EGF/TGFo, FGFs, IGFs, PDGF, VEGF and neurotrophins are known regulators of prostate function [8, 30-33]. Paracrine growth factors secreted by stromal cells and autocrine growth factors produced by epithelial cells mediate the development and proliferation of neoplastic human prostate tissue [30,31]. It is now widely accepted that autocrine growth regulation is at least partially responsible for metastatic potential of cancer cells. Suppression of the invasive phenotype is essential in developing new therapeutic tools to treat prostate cancer, indicating that androgen-independent prostate cancer is characterized by an increased metastatic potential [34].

Various approaches have been used to inhibit or down-regulate neoplastic growth of prostate cancer using suramin, taxol, genistein, erbstatin, soluble receptors, pseudo- ligands, monoclonal antibodies for tyrosine kinase receptors and synthetic receptor tyrosine kinase inhibitors [35-39].

One of the most effective growth factors for prostate cancer cells in vivo and in vitro are the members of EGF family [6,39], and the inhibitors of EGF receptors (ErbB1, ErbB2) are used in clinical treatment of prostate cancer $[6,40,41]$. Autocrine growth stimulation of DU145 cells by EGF/TGF $\alpha$ is well doc- 


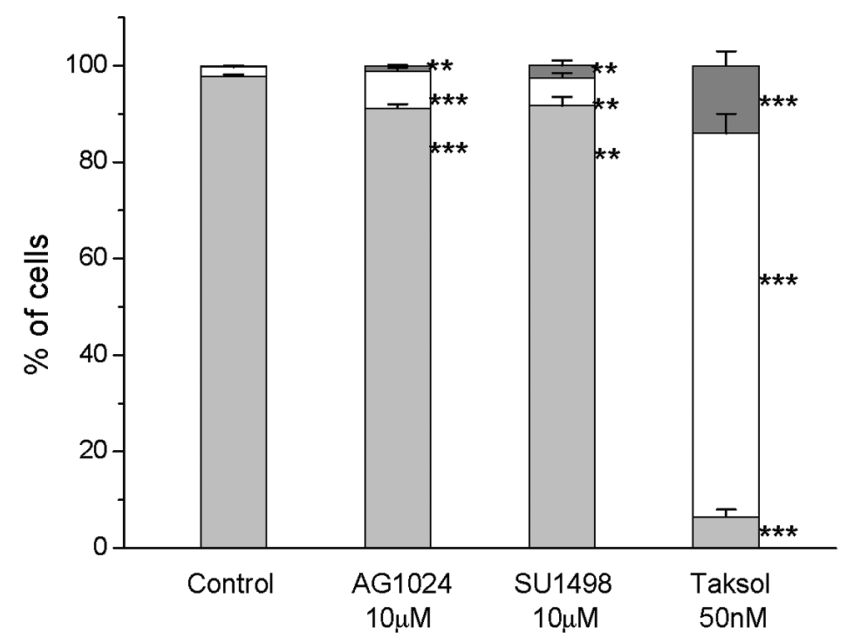

Fig. 3. The effect of tyrphostins: AG1024, SU1498 and taxol (as the positive control) on the induction of apoptosis in DU145 cells, after $48 \mathrm{~h}$ of incubation in DMEM/F12+ medium. The average percentage of: viable cells (black), apoptotic cells (white) and necrotic cells (grey).

*** - $\mathrm{p}<0,001 ; * *-0,001<\mathrm{p}<0,01 ; *-0,01<\mathrm{p}<0,05 ;$ ns - not significant.

umented $[12,13,17]$. However, it has been shown that an acquired resistance to inhibitors of EGFR has been reported clinically [42]. It has been suggested that the resistance is associated with increased signaling through the IGFI receptor [35]. There is still an unresolved question whether prostate cancer itself produces IGFI or the stromal cells provide the peptide. The results of earlier experiments $[8,9]$ indicated that DU145 cells showed overexpression of IGFII and VEGF. These findings in connection with an increased level of IGFRI and VEGFRs suggested the participation of IGFRs and VEGFs in autocrine growth regulation of the investigated cells. There was one in vitro study, which showed that IGFIR antibodies inhibited DNA synthesis in PC3, but not DU145 cell lines [43]; however, other investigators found that IGFIR antibody prevents proliferation of both the prostate cell lines [44]. Although an association may exist between IGFI and prostate cancer, direct causality has not been established [45]. Another question is the role of VEGFR in autocrine growth regulation of prostate cells. Several investigations indicated that VEGF is mainly the angiogenic and chemotactic factor for prostate cancer cells; however, it may regulate tumor growth in vitro [20].

We have determined whether blockade of IGFIR or VEGF2R signaling pathways inhibits autocrine growth and viability of DU145 cells in vitro. Our results indicate that each of the investigated tyrphostins at concentration $>5 \mu \mathrm{M}$ is able to completely inhibit DU145 autocrine cell growth. These results suggest that the two growth factor receptors (IGFIR, VEGFR2) induce a specific signaling route, or activation of one of the investigated receptors influences the
Table 2. The effect of AG1024 and SU1498 on the proportion of DU145 cells in various phases of cell cycle. Cellular DNA contents were measured by flow cytometry (FACS) after $48 \mathrm{~h}$ of incubation with the tyrphostins.

\begin{tabular}{|c|c|c|c|}
\hline \multirow{2}{*}{$\begin{array}{c}\text { Phase } \\
\text { of cell cycle }\end{array}$} & \multicolumn{3}{|c|}{ \% of cellular DNA } \\
\cline { 2 - 4 } & Control & $\begin{array}{c}\text { AG1024 } \\
{[10 \mu \mathrm{M}]}\end{array}$ & $\begin{array}{c}\text { SU1498 } \\
{[10 \mu \mathrm{M}]}\end{array}$ \\
\hline $\mathrm{G}_{1}$ & 58.9 & 73.6 & 71.4 \\
\hline $\mathrm{S}$ & 20.0 & 10.4 & 11.6 \\
\hline $\mathrm{G}_{2}$ & 21.2 & 16.0 & 17.0 \\
\hline $\mathrm{G}_{1}: \mathrm{G}_{2}$ & 2.78 & 4.61 & 4.43 \\
\hline
\end{tabular}

mitogenic pathway of the other. The cytostatic potential of AG1024 $\left(\mathrm{IC}_{50}=2.2 \mu \mathrm{M}\right)$ and $\mathrm{SU} 1498\left(\mathrm{IC}_{50}=2.4\right.$ $\mu \mathrm{M})$ is almost the same. The data on enzymatic specificity of the investigated tyrphostins indicate a different affinity of the tyrphostins to their now-specific tyrosine kinase receptors. A comparison of $\mathrm{IC}_{50}$ values of anti-proliferative and enzyme inhibitory activities (6:1) of AG1024 suggests that the true ligand for IGFIR of DU145 cells is IGFII rather than IGFI, and supports the hypothesis of IGFII/IGFIR autocrine loop in this type of cancer prostate cells [46]. In the case of VEGF receptors, our data (in comparison with the known enzyme inhibitory activity of VEGFR2) indicate the participation of VEGFR1 or/and VEGFR3 in signal transduction induced by VEGF, secreted by DU145 cells.

Differential staining method showed that the investigated tyrphostins, used at concentration $\leq 10 \mu \mathrm{M}$, had little direct cytotoxity on DU145 cell line. The percentage of viable cells after $48 \mathrm{~h}$ of incubation with AG1024 (91.2\%) and SU1498 (91.7\%) was almost the same. The number of apoptotic cells varied from 5.8\% for SU1498 to 7.7\% for AG1024, and was much lower than that determined for $50 \mathrm{nM}$ of taxol (79.6\%). The results of double-staining methods were confirmed by the binding of FITC-labeled Annexin V and exclusion of propidium iodide (PI), followed by an analysis with a FACScan flow cytometer (Becton-Dickinson). The number of viable DU145 cells after treatment with the investigated tyrphostins did not differ from that determined in the control culture (data not shown). These findings indicate that the inhibitory effect of AG1024 and SU1498 is mediated by a cytostatic rather than a cytotoxic mechanism, and differs from the pro-apoptotic effect of EGFR kinase inhibitor ZD1839 [6,16].

Further experiments have revealed that both the investigated inhibitors increased the percentage of DU145 cells in S phase of cell cycle, indicating that AG1024 and SU1498 arrest cell growth in G1 phase, similarly as known inhibitors of EGFR $[6,15]$.

The results of our investigations show that autocrine growth of DU145 my be regulated, at least, 
by additional two autocrine loops: IGFII/IGFIR and VEGF/VEGFRs, despite the well-documented TGF (EGF)/EGFR loop. Multifactor regulation of autocrine growth of metastatic cancer cell lines DU145 may can explain a failure of employing single specific tyrosine kinase inhibitors in therapy (monotherapy) of prostate cancer $[17,47]$. A role for an autocrine growth loop involving tyrosine kinases and their receptors in tumor progression has been suggested for a variety of cancers. Identifying biologically and physiologically important autocrine growth events may have important clinical consequences, also for the introduction of a new strategies in anticancer therapies.

\section{References}

[ 1] Abate-Shen C, Shen MM. Molecular genetics of prostate cancer. Genes Dev. 2000;14: 2410-2434.

[ 2] Marker PC, Donjacour AA, Dahiya R, Cunha GR. Hormonal, cellular, and molecular control of prostatic development. Dev Biol. 2003;253:165-174.

[3] Chatterjee B. The role of the androgen receptor in the development of prostatic hyperplasia and prostate cancer. Mol Cell Biochem. 2003;253:89-101.

[4] Sporn MB, Roberts AB. Autocrine growth factors and cancer. Nature. 1985;313:745-747.

[ 5] Goustin AS, Leof EB, Shipley GD, Moses HL. Growth factors and cancer. Cancer Res. 1986;46:1015-1029.

[6] Bellezza I, Bracarda S, Caserta C, Minelli A. Targeting of EGFR tyrosine kinase by ZD1839 ("Iressa") in androgenresponsive prostate cancer in vitro. Mol Genetics Metabolism. 2006;88:114-122.

[7] Montano X, Djamgoz MBA. Epidermal growth factor, nerotrophins and the metastatic cascade in prostate cancer. FEBS Lett. 2004;571:1-8.

[8] Ferrer FA, Miller LJ, Lindquist R, Kowalczyk P, et al. Expression of vascular endothelial growth factor receptors in human prostate cancer. Urology. 1999;54:567-572.

[ 9] Gennigens C, Menetrier-Caux C, Droz JP. Insulin-like growth factor (IGF) family and prostate cancer. Crit Rev Oncol/Hematol. 2006;58:124-145.

[10] Ozen M, Giri D, Ropiquet F, Mansukhani A, Ittmann M. Role of fibroblast growth factor receptor signaling in prostate cancer cell survival. J Nat Cancer Institute. 2001;93:1783-1790.

[11] Kolibaba KS, Druker BJ. Protein tyrosine kinases and cancer. Biochem Biophys Acta. 1997;1333:F217-F248.

[12] Seth D, Show K, Jazayeri J, Leedman PJ. Complex post-transcriptional regulation of EGF-receptor expression by EGF and TGF- $\alpha$ in human prostate cancer cells. $B r J$ Cancer. 1999;80:657-669.

[13] Salomom DS, Brandt R, Ciardiello F, Normanno N. Epidermal growth factor-related peptides and their receptors in human malignancies. Crit Rev Oncol/Hematol. 1995;19:183232.

[14] Sgambato A, Camerinni A, Faraglia B, et al. Target inhibition of the epidermal growth factor receptor-tyrosine kinase by ZD1839 ('iressa') induced cell-cycle arrest and inhibits proliferation in prostate cancer cells. J Cell Physiol. 2004; 20: $97-$ 105.

[15] Bonaccorsi L, Marchiani S, Muratori M, Fort Baldi E. Gefitinib ('Iressa, ZD1839) inhibits EGF-induced invasion cancer cells by suppressing PI3K/AKT activation. $J$ Cancer Res Clin Oncol. 2004;130(10):604-14.

[16] Vicetini C, Festuccia C, Gravina GL, Angelucci A, Marronaro A, Bologna M. Prostate cancer cell proliferation is strongly reduced by growth factor receptor tyrosine kinase inhibitor ZD1839 in human cell lines and primary cultures. J Cancer Res Clin Oncol. 2003;129:165-174.

[17] Blackledge G. Growth factor receptor tyrosine kinase inhibitors; clinical development and potential for prostate cancer theraphy. J Urol. 2003;170:S77-S83.

[18] Chan JM, Stampfer MJ, Giovanucci E, et al. Plasma insulinlike growth factor-I and prostate cancer risk: a prospective study. Science. 1998;279:563-6.

[19] Riedemann J, Takiguchi M, Sohail M, Macaulay VM. The EGF receptor interacts with the type 1 IGF receptor and regulates its stability. Biochem Biophys Res Commun. 2007;355: 707-714.

[20] Jackson MW, Roberts JS, Heckford SE, et al. A potential autocrine role for vascular endothelial growth factor in prostate cancer. Cancer Res. 2002;62:854-859.

[21] Madhusudan S, Ganesan TS. Tyrosine kinase inhibitors in cancer therapy. Clin Biochem. 2004;37:618-635.

[22] Bennasroune A, Gardin A, Aunis D, Cremel G, Hubert P. Tyrosine kinase receptors as attractive targets of cancer therapy. Crit Rev Oncol/Hematol. 2004;50:23-38.

[23] Lacal JC. Changing the course of oncogenesis: The development of tyrosine kinase inhibitors. EJC Suppl. 2006;4:14-20.

[24] Levitzki A, Gazit A. Tyrosine kinases inhibition: An approach to drug development. Science. 1995;267:1782-1788.

[25] Parrizas M, Gaitz A, Levitzki A, Wertheimer E, LeRoith D. Specific inhibition of insulin-like growth factor- 1 and insulin receptor tyrosine kinase activity and biological function by tyrphostins. Endocrinol. 1997;138:1427-1433.

[26] Strawn LM, McMahon G, App H et al. Flk-1 as a target for growth inhibition. Cancer Res. 1996;56:3540-3545.

[27] Boguslawski G, McGlynn PW, Harvey KA, Kovala AT. SU1498, an inhibitor of vascular endothelial growth factor receptor 2, causes accumulation of fosforylated ERK kinases and inhibits their activity in vivo and in vitro. J Biol Chem. 2004;279:5716-5724.

[28] Gilles RJ, Didier N, Denton M. Determination of cell number in monolayer cultures. Anal Biochem. 1986;159:109-113.

[29] Darzynkiewicz Z, Li X, Gong J. Assay of cell viability: discrimination of cells dying by apoptosis. Methods Cell Biol. 1994;41:138.

[30] Ware J.L. Growth factors and their receptors as determinants in the proliferation and metastasis of human prostate cancer. Cancer Metastasis Rev. 1993;12: 287-301.

[31] Slater M, Barden JA, Murphy C.R. Changes in growth factor expression in the ageing prostate may disrupt epithelial-stromal homeostasis. Histochem J. 2000;32:357-364.

[32] Gowardhan B, West AF, Robson CN, Leung HY. Adenovirusmediated expression of a soluble fibroblast growth factor receptor inhibits in vitro growth of prostate DU145 cells. Prostate. 2004;61:50-59.

[33] Walch ET, Marchetti D. Role of neurotropins and neurotropin receptors in the in vitro invasion and heparanase production of human prostate cancer cells. Clin Exp Metastasis. 1999; 17:307-314.

[34] Marchiani S, Bonaccorsi L, Ferruzzi P, et al. The vitamin D analogue BXL-628 inhibits growth factor-stimulated proliferation and invasion of DU145 prostate cancer cells. J Cancer Res Clin Oncol. 2006;132:408-416.

[35] Jones H.E., Goddard L, Gee J.M.W., Hiscox S., Harper M.E., Rubini M., Barrow D., Guy S., Wakeling A., Nicholson R.I. Insulin-like growth factor-1 receptor signaling and acquired resistance to gefitinib (ZD1839, IRESSA) in DU145 human prostate cancer cells. Endocr Relat Cancer. 2004;11:793-814.

[36] Festuccia C, Angelucci A, Gravina GL, et al. Epidermal growth factor modulates prostate cancer cell invasiveness regulating urokinase-type plasminogen activator activity. 
EGF-receptor inhibition may prevent tumor cell dissemination. Thromb Haemost. 2005;93:964-975.

[37] Oki T, Sowa Y, Hirose T, et al. Genistein induces Gadd45 gene and G2/M cell cycle arrest in the DU145 human prostate cancer cell line. FEBS Lett. 2004;577:55-59.

[38] Turyna B, Jurek A, Gotfryd K, Staśkiewicz A, Kubit P, Klein A. Peritonitis-induced antitumor activity of peritoneal macrophages from uremic patients. Folia Histochem Cytobiol. 2004;42:147-153.

[39] Dassonville O, Bozec A, Fischel JL, Milano G. EGFr targeting therapies: Monoclonal antibodies versus tyrosine kinase inhibitors: Similarities and differences. Crit Rev Oncol/ Hematol. 2007;62:53-61.

[40] Vicentini C, Festuccia C, Gravina GL, Adriano A, Marronaro A, Bologna M. Prostate cancer cell proliferation is strongly reduced by the epidermal growth factor receptor tyrosine kinase inhibitor ZD1839 in vitro on human cell lines and primary cultures. J Cancer Res Clin Oncol. 2003;129: 165-174.

[41] Rabindran S.K. Antitumor activity of HER-2 inhibitors. Cancer Lett. 2005;227:9-23.

[42] Jimeno A, Hidalgo M. Blockade of epidermal growth factor receptor (EGFR) activity. Crit Rev Oncol/Hematol. 2005;53: 179-192.

[43] Kimura G, Kasuya J,Giannini S, et al. Insulin-like growth factor (IGF) system components in human prostatic cancer cell-lines. Int J Urol. 1996;3:39-46.
[44] Maloney EK, McLaughlin JL, Dagdigian NE, Garrett LM, Connors KM, Zhou XM, Blättler WA, Chittenden T, Singh R. An anti-insulin-like growth factor I receptor antibody that is a potent inhibitor of cancer cell proliferation. Cancer Res. 2003;63:5073-5083.

[45] Meinbach DS, Lokeshwar BMD. Insulin-like growth factors and their binding proteins in prostate cancer: Cause or consequence? Urol Oncol Seminars Orginal Invest. 2006;24:294306.

[46] Figuerola JA, Lee AV, Jackson JG, Yee D. Proliferation of cultured human prostate cancer cells is inhibited by insulin-like growth factor (IGF) binding protein-1: evidence for an IGF-II autocrine growth loop. $J$ Clin Endocrionol Metab. 1995;80:3476-3482.

[47] $\mathrm{Pu}$ YS, Hsieh MW, Wang CW et al. Epidermal growth factor receptor inhibitor (PD168393) potentiates cytotoxic effects of paclitaxel against androgen-independent prostate cancer cells. Biochem Pharmacol. 2006;71:751-760.

Submitted: 5 October, 2007 Accepted after reviews: 17 January, 2008 